\title{
The Sustainability of Cultural Diversity in the Workplace: Cultural Values and Intercultural Mindset
}

\author{
Anikó Tompos ${ }^{1}$ and Lívia Ablonczy-Mihályka²
}

\begin{abstract}
The last two decades saw the emergence of culturally diverse workplaces in Hungary. Researchers usually agree that cultural heterogeneity is an asset and contributes to the sustainability and competitive advantage of firms provided some conditions are met, that is multiple identity workgroups in themselves do not automatically bring positive benefits. Effective work across cultural differences necessitates an increase in cross-cultural intelligence and competence and parallel to this, a decrease in ethnocentrism. The purpose of the paper is to present and discuss the findings of a questionnaire survey $(\mathrm{N}=367)$, which set out to map out how Hungarian companies and enterprises manage cultural diversity and to measure business actors' cultural sensitivity. In particular, it looks at differences between generations $\mathrm{X}$ and $\mathrm{Y}$ in terms of their intercultural mindset, i.e. their thinking, emotions and attitudes towards diversity. The study concludes that Hungarian businesspeople who work with people of different cultural backgrounds, regardless of age, do not display the ethnocentric and exclusionary attitudes which characterise the society and seem to have sufficient levels cross-cultural intelligence to meet the cultural diversity challenge.
\end{abstract}

Keywords: cultural diversity, generations, intercultural mindset, sustainability

\section{Introduction}

The present study sets out to examine the cultural and work-related values and intercultural mindset or 'heartset' (Bennett and Bennett, 2004: 149) of Hungarian businesspeople. In particular, it aims to detect generation-related differences in their thinking, emotions and attitudes towards cultural diversity. The rationale behind the investigation is the growing number of culturally diverse workplaces in Hungary, which necessitates employees who are able to cooperate with employees whose national culture, values and norms are different.

Cultural heterogeneity is usually seen as an asset, which contributes to the sustainability and competitive advantage of firms. However, multiple identity workgroups in themselves do not automatically bring positive benefits. Effective work across cultural differences necessitates an increase in cross-cultural intelligence and competence and parallel to this, a decrease in ethnocentrism (Némethová, 2015). Cooperation is a must, at the same time, both in long- and short-term transnational teams conflicts may arise due to different perceptions of justice and fairness as well as incompatible goals, attitudes or behaviour (Stohl et al., 2013: 713-714). Thus, cross-cultural differences can interfere with companies' plans to strengthen their competitive position.

The first part of the paper gives a brief overview of Hungarian societal and work-related values, attitudes to foreigners and generational differences. The second part discusses the 
methods and results of a questionnaire survey, examining the attitudes of Hungarian businesspeople towards workplace diversity.

\section{Generational Differences in Societal Values and Attitudes to Work}

Intercultural diversity at Hungarian workplaces, which only a little more than two decades ago was a rare and unique phenomenon, is now a fact of life, mainly in the business sector. Thus, it is a novel challenge for Hungarians to work in and manage culturally diverse groups with diverse cultural values, norms and expectations. A substantial body of research has been carried out in an effort to examine different aspects of international cooperation and intercultural communication. For example, Konczosné Szombathelyi et al. (2016) studied the cross-border communication management strategies of multinational companies, Szőke (2016) examined negotiations in a bicultural setting, Kecskés (2017) discussed the role of geographical proximity in the internal communication of multinationals, Tompos and Ablonczy-Mihályka (2017) surveyed the impact of intercultural training programmes on employees' attitudes, while Nádai (2017) looked at stereotypes, to name but a few researchers and lines of investigation.

Against this economic reality is the psychological reality that the Hungarian society is quite ethnocentric and has very low levels of trust in foreigners. Messing and Ságvári (2016) compared data from the 2002 and 2015 rounds of the European Social Survey and concluded that exclusionary and isolationist attitudes were on the increase. They found, among others, that the number of those who would not be disturbed by having a foreigner as their boss or as the spouse of a close relation has dropped from $27 \%$ to $13 \%$. The Randstad survey, which is carried out each year, shows that for Hungarian employees the most important factor when choosing a workplace is salary and benefits (2015: 81\%, 2016: 82\%, 2017: 74\%). In 2017 workplace atmosphere came second (2015: 50\%, 2016: 51\%, 2017: 61\%), changing place with long-term job security (2015: 62\%, 2016: $62 \%, 2017: 56 \%$ ). The importance of effective treatment of diversity has also risen (2015: 8\%, 2016: 7\%, 2017: 11\%), at the same time that of international career opportunity has substantially dropped (2015: 10\%, 2016: 8\%, 2017: 4\%).

Specialist literature describes five present-day generations: veterans born between 1920 and 1944, babyboomers born between 1945 and 1959, generation X born between 1960 and 1979, generation Y born between 1980 and 1994 and generation Z born between 1995 and 2010 (since there is little agreement on the years encompassing the above generations, for a more refined downbreak and an overview of sources see Srinivasan, 2012). Certainly, historical, political or societal changes and events allow for different categorizations even within the same country. For example, Róbert and Valuch (2013) discuss 8 political generations and 5 historical generations who at present live in Hungary.

Researchers from various specialist fields have approached different aspects of the generation gap (see, for example Ercsey, 2017; Makkos-Káldi et al., 2013; Nádai and Garai, 2017; Ridley et al., 2011; Szőke and Kovács, 2014; Tompos and AblonczyMihályka, 2015). Below is a brief description of four generations of Hungarians currently on the labour market, as depicted in specialist literature. 
Veterans and many babyboomers are no longer on the Hungarian labour market since until 1999 the retirement age was 60 but women were allowed to retire as young as 55 . The babyboom generation is usually characterized by loyalty, reliability, professional knowledge as well as respect for experience and traditions. Gen Xers faced the rapidly changing world of technology and also the settlement of multinational companies in Hungary accompanied by unlimited working hours and workplace stress. Its members are not only controlled and adept but also highly motivated, money-minded and careeroriented. At the same time, since they were socialised and started work in the communist era, they are still cooperative and collectivistic.

Gen Yers are talented and creative; they possess high-level technological skills and a hunger for information resulting in flexibility and an ability to fit into multicultural teams. At the same time, due to multitasking, they do not strive to gain thorough professional knowledge, are willing to take too many risks and are often impatient. Unlike their parents and grandparents, they are not attached to their workplace and do not strive for lifelong employment. Generation $\mathrm{Z}$ is practical, has good problem-solving skills but are not so good at solving conflicts. Information communication is their 'mother tongue' and they are very good at information sharing. They do not respect authority, which is a consequence of their reverse socialisation.

Dósa et al. (2014) claim that Hungarian Gen Yers are expected to possess certain core competencies which enable them to realise their own plans as well as to successfully integrate into the increasingly multicultural society and labour market. They emphasise the importance of the ability to (1) carry out autonomous actions, (2) interactively use (communication) tools and (3) cooperate in heterogeneous societal and labour groups. The third requirement necessitates interpersonal, cultural and intercultural skills. According to Draghici (2015: 63), cultural competence comprises four components: (1) awareness of one's own cultural worldview, (2) attitude towards cultural differences, (3) knowledge of different cultural practices and worldviews and (4) cross-cultural skills. She (Draghici 2015, 64-65) considers empathy, an understanding of other people's behaviour and ways of thinking, and the ability to express one's own way of thinking intercultural competence and sees it as a balance among four parts: (1) knowledge about other cultures and other people's behaviour, (2) empathy towards the feelings and needs of other people, (3) self-confidence, i.e. the knowledge of one's own desires, strengths, weaknesses, and emotional stability and (4) cultural identity that is linked with the knowledge of one's own culture.

\section{Purpose and Methods}

The study reported in this paper aimed to find out whether there are differences in the intercultural mindset of the young generation of Hungarian businesspeople and that of the older $(35+)$ generation. The data come from a questionnaire survey $(\mathrm{N}=367)$ which was completed by Hungarian business professionals who work together with people of different cultural backgrounds. Convenience sampling was used to recruit respondents.

The respondents' demographic data are as follows: a total of 186 male and 176 female business professionals filled in the questionnaire while 2 subjects did not state their 
gender. 299 of them hold a bachelor's or master's degree and 67 did not take part in tertiary studies. 20 claimed they are in upper managerial positions, 52 are middle managers and 292 are employees. 88 subjects have ancestors of not Hungarian background and 167 stated they had spent a longer time abroad during their studies or work. As for age, 238 respondents are aged between 20-35, 85 between 36 and 45, 22 between 46 and 50, and only 17 over 51 years of age. 5 respondents failed to state their age.

The subjects were asked to rate the following statements on a five-point Likert scale (1: fully disagree, 2: disagree, 3 neither agree nor disagree, 4: agree, 5: fully agree):

1. Cultural differences cause tensions in the workplace.

2. It is important to know our own culture when we work together with foreigners.

3. Cultural differences among workers are a marginal factor in the workplace.

4. We cannot work together with foreigners without tolerance.

5. Stereotypes help us understand other cultures.

6. Cultural differences among participants are an advantage during teamwork.

7. My superior helps me to understand and communicate with colleagues of a different cultural background.

8. Co-workers with different cultural backgrounds perform better when working together.

9. Hungarians prefer to work only with Hungarians.

10. There are certain positions where a different cultural background can be an advantage.

11. Co-workers' different cultural backgrounds result in new ideas, new knowledge and new approaches to solving tasks.

12. My company forms its strategy so that it suits its workers with different cultural backgrounds.

13. Cultural differences help us become more innovative.

14. Promotion at my company depends on performance, not on cultural background.

15. The difference between Hungarian and foreign employees is beginning to fade.

16. It is possible to predict potential disagreement due to cultural differences.

SPSS 22.0 was used to process the questionnaires. The analysis below relies on the information gained from 367 respondents. However, the tables below in some cases contain fewer responses due to missing data.

\section{Findings and Discussion}

For the purposes of the present study, the age groups were reduced to two, representing Generation X (and, to a lesser extent, Babyboomers) and Generation Y (and, to a lesser extent, Generation Z). For purposes of ease, the two groups will henceforth referred to as Gen Xers (or the older generation) and Gen Yers (or the young generation). As Table 1 shows, the number of the young generation is almost double of that of the older generation. This is a seen as a consequence of availability sapling. 
Table 1: Age groups in the survey

\begin{tabular}{|ll|c|c|c|c|}
\hline & & Frequency & Percent & Valid Percent & Cumulative Percent \\
\hline \multirow{3}{*}{ Valid } & between 20-35 & 238 & 64.9 & 65.7 & 65.7 \\
& over 36 & 124 & 33.8 & 34.3 & 100.0 \\
& Total & 362 & 98.6 & 100.0 & \\
Missing & System & 5 & 1.4 & & \\
Total & & 367 & 100.0 & & \\
\hline
\end{tabular}

Respondents' attitudes are presented in Table 2. As we can see, in the case of each statement, there were subjects who completely accepted or rejected the idea. Subjects were most unanimous in case of three statements: There are certain positions where a different cultural background can be an advantage; Co-workers' different cultural backgrounds result in new ideas, new knowledge and new approaches to solving tasks; Cultural differences help us become more innovative. The lowest degree of unanimity can be seen with the view expressed by the statement My superior helps me to understand and communicate with colleagues of a different cultural background. Respondents were also of different opinions when stating their opinion on Hungarians prefer to work only with Hungarians and Cultural differences among workers are a marginal factor in the workplace.

Table 2: Descriptive statistics - attitude statements

\begin{tabular}{|l|c|c|c|c|c|}
\hline Cultural differences cause tensions & $\mathrm{N}$ & Min & Max & Mean & Std. D. \\
It is important to know our own culture & 361 & 1 & 5 & 2.48 & 1.046 \\
Cultural differences are a marginal factor & 364 & 1 & 5 & 3.62 & 1.062 \\
We cannot work together without tolerance & 365 & 1 & 5 & 2.70 & 1.164 \\
Stereotypes help us understand cultures & 365 & 1 & 5 & 3.98 & 1.091 \\
Cultural differences are an advantage & 360 & 1 & 5 & 2.61 & 1.076 \\
My superior helps me to understand & 358 & 1 & 5 & 3.10 & 1.107 \\
International teams perform better & 365 & 1 & 5 & 2.91 & 1.269 \\
Hungarians prefer to work with Hungarians & 365 & 1 & 5 & 2.87 & 1.031 \\
There are positions where a different cultural & 365 & 1 & 5 & 3.25 & 1.167 \\
Different cultural backgrounds: new ideas & 365 & 1 & 5 & 3.78 & .995 \\
My company forms its strategy to suit & 365 & 1 & 5 & 4.00 & .981 \\
Cultural differences help be more innovative & 365 & 1 & 5 & 3.58 & 1.080 \\
Promotion depends on performance & 364 & 1 & 5 & 3.73 & .993 \\
Cultural differences are beginning to fade & 364 & 1 & 5 & 3.00 & 1.157 \\
It is possible to predict potential conflicts & 365 & 1 & 5 & 2.92 & 1.035 \\
\hline
\end{tabular}

The majority of respondents seem to accept the view that culturally heterogeneous teams create new ideas, new knowledge and new approaches to solving tasks, and, moreover, that multicultural teams are more innovative. At the same time, they seem to acknowledge international teams' better performance and their advantageousness to a lesser extent. The majority of subjects also agreed with the view that tolerance is indispensable when working together with people of different cultural backgrounds. However, they think it is important for individuals to be familiar with their own cultural values. Respondents do not seem to agree with the idea that cultural differences cause 
tensions in the workplace nor do they think stereotypes are helpful when it comes to the understanding of cultural norms other than their own.

A weak but significant difference between the opinions of the two age groups of respondents was only found with regard to one statement: Stereotypes belp us understand other cultures (Table 3). It is the older generation that seems to accept reliance on stereotypes to a greater extent. Three potential causes have been formulated: (1) Gen Xers have learned it from their own work experience that descriptive stereotypes might be useful for cultural newcomers, and also they might already have their own stereotypes based on their or their peers' observations. (2) Gen Yers, most of whom have taken part in intercultural training programmes, reject stereotypes, since effective stereotyping is rarely a part of intercultural trainings. (3) Gen Yers, being experimental and unconventional, do not appreciate pre-prepared recipes coming from old wisdom.

Table 3: Stereotypes help us understand other cultures

Crosstab

Count

\begin{tabular}{|ll|c|c|c|}
\hline & & Age groups & \multirow{2}{*}{ Total } \\
\cline { 3 - 4 } & & $20-35$ & $36+$ & \\
\hline & I fully disagree & 46 & 18 & 64 \\
Stereotypes help us understand other cultures & I disagree & 67 & 38 & 105 \\
& neutral & 73 & 34 & 107 \\
& I agree & 50 & 26 & 76 \\
Total & I fully agree & 1 & 7 & 8 \\
\hline
\end{tabular}

Chi-Square Tests

\begin{tabular}{|l|c|c|c|}
\hline & Value & df & Asymp. Sig. (2-sided) \\
\hline Pearson Chi-Square & $11.619^{\mathrm{a}}$ & 4 &, 020 \\
Likelihood Ratio & 11.380 & 4 &, 023 \\
Linear-by-Linear Association & 2.153 & 1 &, 142 \\
N of Valid Cases & 360 & & \\
\hline
\end{tabular}

a. 1 cells $(10.0 \%)$ have expected count less than 5 . The minimum expected count is 2.73 .

Symmetric Measures

\begin{tabular}{|ll|c|c|}
\hline & & Value & Approx. Sig. \\
\hline Nominal by Nominal & Phi & .180 & .020 \\
N of Valid Cases & Cramer's V & .180 & .020 \\
& & 360 & \\
\hline
\end{tabular}

It should be noted here that the data discussed in this paper has already been examined using respondents' participation in intercultural training programmes as an independent variable (Tompos and Ablonczy-Mihályka, 2017). It has been found that participation in intercultural trainings does not seem to have significantly affected the respondents' intercultural mindset. The examination of the content of intercultural trainings the subjects took part in has confirmed results of previous investigations, namely that 
contents are quite conventional.

Table 4 shows the attitude statement means for the two age groups. Due their generational characteristics, for example flexibility and openness, and deeper exposure to foreign cultures, generation $\mathrm{Y}$ had been expected to display more favourable attitudes towards diversity. As we can see, some averages are in fact slightly higher than those of Gen Yers. For example, young businesspeople expect fewer cultural difference-related conflicts, more accept the ideas that cultural difference may be an advantage during teamwork, multinational teams perform better, cultural differences fuel innovation and different cultural backgrounds result in new ideas, new knowledge and new approaches to solving tasks. Moreover, they seem to experience the fading of cultural differences and think they are not so important. However, they believe tolerance is a necessary characteristic when working together with foreigners.

Table 4: Differences between the attitudes of Gen X and Gen Y

\begin{tabular}{|l|c|c|}
\hline & Mean 20-35 & Mean 36+ \\
\hline Cultural differences cause tensions & 2.43 & 2.60 \\
It is important to know our own culture & 3.60 & 3.73 \\
Cultural differences are a marginal factor & 2.65 & 2.80 \\
We cannot work together without tolerance & 3.90 & 4.10 \\
Stereotypes help us understand cultures & 2.55 & 2.72 \\
Cultural differences are an advantage & 3.14 & 3.02 \\
My superior helps me to understand & 2.88 & 2.96 \\
International teams perform better & 2.87 & 2.85 \\
Hungarians prefer to work with Hungarians & 3.28 & 3.25 \\
There are positions where a different cultural & 3.78 & 3.74 \\
Different cultural backgrounds: new ideas & 4.05 & 3.88 \\
My company forms its strategy to suit & 3.64 & 3.48 \\
Cultural differences help us be more innovative & 3.78 & 3.67 \\
Promotion depends on performance & 3.75 & 3.62 \\
Cultural differences are beginning to fade & 3.06 & 2.05 \\
It is possible to predict potential conflicts & 2.90 & 3.00 \\
\hline
\end{tabular}

Respondents representing the older generation feel even more that tolerance is needed when working in multicultural teams. They seem to be more aware of cultural differencerelated tensions and conflicts, at the same time, they believe these can be predicted. For them it is more important to know their own cultural values and norms.

\section{Conclusions}

It is a widely accepted view that organisations can take advantage from workforce diversity. Indeed, workforce is increasingly multicultural and the business environment is now global. However, cultural differences can hinder companies' plans to enhance their competitive position. Thus, it is a must to cater for the successful implementation and sustainability of diversity.

The study reported in this paper examined Hungarian businesspeople's attitudes towards diversity in the workplace. The Hungarian society is found ethnocentric and exclusionary 
in sociological surveys. At the same time, as workplaces, especially in the business sector, are becoming more and more international, the importance of effective treatment of diversity, as a motivating factor when choosing a workplace, has grown.

The authors are aware of the limitations of their research. Nonetheless, the results allow for some conclusions. The findings seem to indicate that Hungarian businesspeople do not display too ethnocentric attitudes and have increased levels of cross-cultural awareness and intelligence. Businesspeople representing generation $\mathrm{Y}$ appear to be slightly more aware of the importance of cross-cultural differences and also to some degree believe more in the advantages of multicultural teams. Gen Xers' intercultural mindset seems to be very similar to that of Gen Yers, except that for them it is more important to know their own culture and they feel more tolerance is needed when working with people of diverse cultural backgrounds. They seem to be more attuned to cultural difference-related conflicts, yet they believe these can be predicted. Thus, we can conclude that both generations appear to be able to meet the cultural diversity challenge and to work effectively across cultural differences.

\section{Acknowledgements}

The research reported in the study was carried out in the framework of the project EFOP-3.6.1-16-2016-00017 Internationalisation, initiatives to establish a new source of researchers and graduates, and development of knowledge and technological transfer as instruments of intelligent specialisations at Széchenyi István University

\section{References}

Bennett, J. M. \& Bennett, M. J. (2004). Developing Intercultural Sensitivity: an Integrative Approach to Global and Domestic Diversity. In Landis, D., Bennett, J. M. \& Bennett, M. J. (eds.) Handbook of Intercultural Training. 3rd ed. Thousand Oaks, CA: Sage. pp. 147-165.

Dósa, I., Magyar, G. \& Király, L. (2014). Generation Y - self-confidence? Economica, 7(4), 25-32. Retrieved from http://docplayer.hu/17303246-A-szolnoki-foiskola-tudomanyos-kozlemenyei.html

Draghici, A. (2015). The Importance of Cross-Cultural Competencies in the New Context of Human Resources Management. In Rakowska, A. \& Babnik, K. (eds) Human Resources Management Challenges: Learning and Development. Bankok, Celje, Lublin: ToKnow Press. pp. 63-89.

Kecskés, P. (2017). The role of geographical proximity in inter-organizational communication. Selye E-Studies, 8(1), 15-23. Retrieved from http://selyeuni.sk/ef/e-studies/en/past-issues.html?start =5

Konczosné Szombathelyi, M., Borgulya, I. \& Szondi, Gy. (2016). Managing cross-border intern corporate communication of international companies. Organizaciju Vadyba: Sisteminiai Tyrimai, (75), 71-82.

Ercsey, I. (2017). Vevői involvement generációs kitekintésben. In Reisinger A. \& Kecskés P. (eds.) "Ifjúság jövöképek": Kautz Gyula Emlékkonferencia. Györ: Széchenyi István Egyetem. Retrieved from http://kgk.sze.hu/images/dokumentumok/kautzkiadvany2016/ErcseyI.pdf

Makkos-Káldi, J., Eisingerné Balassa, B. \& Kecskés, P. (2013). Aranyat ér-e az ezüstgeneráció? Tér-GazdaságEmber, 1(1), 119-134.

Messing, V. \& Ságvári, B. (2016). „Ahogy »másokhoz« viszonyulunk, az tükrözi azt, amilyenek magunk vagyunk" A magyarországi idegenellenesség okairól. SOCIO.HU: Társadalomtudományi Szemle, (2), 17-37. Retrieved from http://socio.hu/uploads/files/2016_2/messing_sagvari.pdf

Nádai, J. (2017). Stereotypes: An obstacle or trigger to business succes? European Journal of Sustainable Development, 6(1), 174-180.

Nádai, J. \& Garai, A. (2017). A Question of Time: Relations Between Age and Business Success. European Journal of Sustainable Development, 6(1), 325-334. 
Némethová, I. (2015) Cultural sensitivity and diversity awareness. In Tompos A. \& Ablonczyné Mihályka L. (eds.) "Kitekintések: 25 éves a györi közgazdászképzés: Kautz Gyula Emlékekonferencia. Győr: Széchenyi István Egyetem. Retrieved from http://kgk.sze.hu/images/dokumentumok/kautzkiadvany2015/Nemethova.pdf

Ridley, J., D'Silva, K. \& Szombathelyi, M. (2011). Sustainability assurance and internal auditing in emerging markets. Corporate Governance, 11(4), 475-488.

Róbert, P. \& Valuch, T. (2013). Generations in history and society. Political attitudes and patterns of participation in a historical sociological approach. Politikatudományi Szemle, 22(4), 116-139.

Srinivasan, V. (2012). Multi generations in the workforce: Building collaboration. IIMB Management Review, 24(1), 4866. Retrieved from http://www.sciencedirect.com/science/article/pii/S0970389612000055

Stohl, C., McCann, R. M. \& Bakar, H. A. (2013). Conflict in the Global Workplace. In: Oetzel J. G., TingToomey S. (eds.) The SAGE handbook of conflict communication: Integrating theory, research and Practice, 2nd ed. Los Angeles, CA: SAGE, pp. 713-736.

Szőke, J. \& Kovács, N. (2014). Kis- és középvállalkozások képviselőinek üzleti magatartása kultúraközi interakciós helyzetekben. Társadalomkutatás, (2), 162-175.

Szőke, J. (2015). The Cultural Aspect of Austro-Hungarian Business Negotiations. International Journal of Business and Management Studies, 4(1), 47-52. Retrieved from

http://www.universitypublications.net/ijbms/0401/html/DE4C442.xml

Tompos, A. \& Ablonczy-Mihályka, L. (2015). What makes a good business negotiator? - Hungarian practitioners' preferences. Sociokulturnyje Problemy Jasylka i Kommunikacii: Sbornik Naucnych Trudov, (10), 114-120.

Tompos, A. \& Ablonczy-Mihályka, L. (2017). Cultural Diversity in the Workplace: Exploring the Impact of Intercultural Trainings on the Attitudes of Business Actors. International Journal of Arts and Sciences, 9(4), 91-100. 